\title{
Clinicopathological features and immunohistochemical detection of antigens in acute experimental Streptococcus agalactiae infection in red tilapia (Oreochromis spp.)
}

\author{
Syuhaidah Abdullah', Noraini Omar ${ }^{1}$, Sabri Mohd Yusoff ${ }^{1,2^{*}}$, Emikpe Benjamin Obukwho',
}

Tanko Polycarp Nwunuji ${ }^{1}$, Latifah Hanan ${ }^{1}$ and Jamil Samad ${ }^{1}$

\begin{abstract}
This study investigates the clinicopathological features of acute experimental streptococcosis in red tilapia using various routes of infection; intraperitoneal (IP), immersion (IM) and immersion cut (IC). Twenty four red tilapia in duplicates were inoculated intraperitoneally with $10^{9} \mathrm{CFU} / \mathrm{ml}$ of $\mathrm{S}$. agalactiae while another sets: intact, one with sharp cut at the tail end were exposed to bacterial inoculums $10^{9} \mathrm{CFU} / \mathrm{ml}$ diluted in water while two groups of control fish were similarly manipulated. Clinical signs were recorded; samples from the gills, brain, eyes and kidneys were also taken for bacterial isolation and histopathology. Immunohistochemistry (IHC) and polymerase chain reaction (PCR) were employed to detect the antigen. The diseased fish showed skin, fin haemorrhages and exophthalmia with obvious signs in IP at $2 \mathrm{hpc}$ followed by IC and IM at $4 \mathrm{hpc}$. The lesions were noticed earlier in the kidney and most severe in IP. IHC detected antigen as early as PCR and isolation with intense staining in blood vessel lumen and wall, macrophages in choroid, focal haemorrhage in the renal interstitium and meninges especially in IP followed by IC and IM. The immunolocalisation of the antigen described for the first time further explain the pathogenesis of streptococcosis in red tilapia.
\end{abstract}

Keywords: Red tilapia; Streptococcus agalactiae; infection; IHC; PCR

\section{Introduction}

Tilapia (Oreochromis spp.) are reported to be among the most cultured food fish worldwide (Klesius et al. 2008). About $80 \%$ of the global farmed tilapia production in 2002 showed Asia as the largest world producer. Among the Asian countries, Malaysia is listed among the top ten producers of farmed tilapia (El-Sayed 2006). Tilapia, also known as "aquatic chicken" are fast growing with ability to survive in poor water conditions. They are white flesh, eat variety of food, easy to breed with simple and noncomplicated hatchery technology (Nandlal and Pickering 2004). In terms of resistance, tilapia were also considered

\footnotetext{
* Correspondence: sabri@vet.upm.edu.my

${ }^{1}$ Department of Veterinary Pathology \& Microbiology, Faculty of Veterinary Medicine, Universiti Putra Malaysia, 43400 UPM, Serdang, Selangor, Malaysia ${ }^{2}$ Faculty of Veterinary Medicine, Universiti Putra Malaysia, 43400, Serdang, Selangor, Malaysia
}

to be relatively resistant to bacterial, fungal, parasitic and viral diseases (Klesius et al. 2008).

Red tilapia (Oreochromis niloticus hybrid) were first introduced in mid-1980's in Malaysia possibly due to their relative resistance to disease. In 1997, there was heavy mortality of about 300 to $400 \mathrm{~g}$ weight tilapia that were kept in floating net cages in Sungai Pahang (Siti-Zahrah et al. 2004), the fish showed clinical features of corneal opacity, exophthalmia, erratic swimming and occasional swollen abdomen, with mortality rate of $70 \%$. Other similar outbreaks were recorded in cages of Kenyir, Pedu and Pergau Lakes in Malaysia in the mid year between April to July and the laboratory investigation conducted revealed the causative agent to be Gram-positive bacteria, S. agalactiae (Siti-Zahrah et al. 2005; Amal et al. 2008).

S. agalactiae had been identified as a pathogen responsible for causing infections in a wide range of hosts; chicken, camel, dolphin, horse, monkeys, cats, dogs, rabbits, nutrias,

in any medium, provided the original work is properly cited. 
guinea pigs and mice (Garcia et al. 2008). It is well known to cause septicaemia and meningo-encephalitis in fish which include rainbow trout, seabream, tilapia, yellowtail, catfish spp., killifish, menhaden spp., mullet, and silver pompfret (Ferguson et al. 1994; Olivares-Fuster et al. 2008).

Streptococcus spp. has been reported to cause morbidity and mortality worldwide with estimated loss of about $\$ 150$ million annually (Klesius et al. 2008). Among the variety of freshwater and saltwater fish species, $S$. agalactiae had been shown to cause high morbidity and mortality (Pasnik et al. 2006; Garcia et al. 2008). However, the pathogenesis of the infection in fish is still poorly understood (Eldar et al. 1995). In Malaysia, the outbreak of $S$. agalactiae has been reported as one of the emerging pathogen in tilapia culture (Abuseliana et al. 2011) and the clinicopathological changes associated with natural infection had been earlier described (Zamri-Saad et al. 2010). Therefore, there is need to properly understand the disease for its eventual control especially as regards the distribution of the bacterial antigen in tissues of the fish in acute and chronic infection with the use of PCR and IHC.

Infection through water is the most popular means of pathogen transmission in Streptococcus spp. infection and several transmission routes had been employed experimentally (Agnew and Barnes 2007) especially infection via IM and IP routes. However, there is very little information on the susceptibility to infection when there is skin abrasion, which is a possible scenario on the field (Chang and Plumb 1996; Shoemaker et al. 2000). This study therefore evaluates the possible role of skin cut in the transmission of $S$. agalactiae and it also described the clinicopathological changes and the detection of $S$. agalactiae antigen in the tissues of experimentally infected red tilapia by routine bacterial isolation, PCR and IHC.

\section{Materials and methods \\ Fish}

A total of 192 red tilapia (Oreochromis sp.), apparently healthy fish were obtained from an Aquaculture Extension Centre (AEC), Department of Fisheries Malaysia, Bukit Tinggi, Pahang. Fish with weight between 100-150 g were selected for the study. Prior to experiment, tanks were disinfected and cleaned. The source of water was dechlorinated and continuously aerated. Water quality was monitored and maintained throughout the experiment. The fish used, were screened for bacteria (particularly for $S$. agalactiae and external parasites). The fish were fed ad libitum with commercial feed before the experiment but throughout the experiment, the fish were off feed.

\section{Bacteria}

S. agalactiae isolated from previous outbreak was used for the study (Siti-Zahrah et al. 2005). The organism was maintained in stock agar and also in glycerol stock. The bacteria stocked in nutrient agar were subcultured onto blood agar (Oxoid, UK) and incubated at $30^{\circ} \mathrm{C}$ for $24 \mathrm{~h}$ (Evans et al. 2004). The brain heart infusion broth (BHIB, Oxoid, UK) was used to subculture the colony and incubated in shaker incubator at $30^{\circ} \mathrm{C}$ for $24 \mathrm{~h}$. A serial dilution and standard plate count techniques were used to determine the bacteria concentration (Alcamo 1997). $0.1 \mathrm{ml}$ from the highest dilution was poured and spread onto the blood agar and incubated at $30^{\circ} \mathrm{C}$ for $24 \mathrm{~h}$. Between 25 to 250 colonies were counted before the concentration was expressed as colony forming unit per millilitre (CFU/ml). The last concentration of live $S$. agalactiae used for inoculation was $10^{9} \mathrm{CFU} / \mathrm{ml}$.

\section{Experimental design}

The experiment was done by challenging the fish with $10^{9} \mathrm{CFU} / \mathrm{ml}$ of live $S$. agalactiae using different routes of infection. The fish $(\mathrm{n}=192)$ were divided into four groups with duplicates. Group $1(n=24)$ were exposed to $S$. agalactiae through intraperitoneal (IP) route and transferred into the $6 \mathrm{~L}$ tank, Group $2(\mathrm{n}=24)$ were exposed to S. agalactiae through immersion bath (IM) (5 L of water + $1 \mathrm{~L}$ of $S$. agalactiae broth) for $10 \mathrm{~min}$ before being transferred into the $6 \mathrm{~L}$ tank and Group $3(\mathrm{n}=24)$ were exposed to $S$. agalactiae through immersion bath $(5 \mathrm{~L}$ of water $+1 \mathrm{~L}$ of $S$. agalactiae broth) for $10 \mathrm{~min}$ with the body of fish being incised (IC) $(0.5 \mathrm{~cm})$ at the caudal part before being transferred into the $6 \mathrm{~L}$ tank. Group $4(\mathrm{n}=24)$ was the control unchallenged group. The fish were kept for $24 \mathrm{~h}$ off fed and the clinical signs were observed continuously within $24 \mathrm{~h}$ duration of the experiment. The gills, brain, eyes and kidney were collected from three fish four hourly within $24 \mathrm{~h}$. The tissue samples were subjected to bacterial culture, PCR, histopathology and IHC.

\section{Bacteria isolation and identification Bacteria culture}

The swab from the organs that were collected four hourly were immediately streaked onto the blood agar plates (Evans et al. 2004) and incubated at $30^{\circ} \mathrm{C}$ for $24 \mathrm{~h}$. Gram staining were performed to identify Gram-positive cocci in chain or paired and catalase test negative organisms. Finally, the colonies were further characterized using the commercialized test kit, API rapid ID 32 Strep ${ }^{\bullet}$ (bioMerieux SA, Marcy I’Etoile, France).

\section{PCR}

For confirmation of $S$. agalactiae, total cellular DNA was extracted using Wizard Genomic DNA Purification Kit (Promega, USA) according to manufacturer's protocol. The extracted DNA was then further evaluated by PCR for S. agalactiae-specific section of 16S-23S rRNA intergenic spacer region with primers STAUR 4 [ACG GAG TTA CAA AGG ACG AC] and 6 [AGC TCA GCC TTA ACG 
AGT AC], and cycling conditions described as follows; 1 cycle at $94^{\circ} \mathrm{C}$ for $4 \mathrm{~min}$, followed by 34 cycles at $94^{\circ} \mathrm{C}$ for $1 \mathrm{~min}, 52^{\circ} \mathrm{C}$ for $1 \mathrm{~min}, 72^{\circ} \mathrm{C}$ for $1 \mathrm{~min}$ and finally elongation at $72^{\circ} \mathrm{C}$ for $10 \mathrm{~min}$. Seven $\mu \mathrm{l}$ of the amplified products was electrophoresed using $1.0 \%(\mathrm{w} / \mathrm{v})$ agarose gel in $1 \times$ TBE electrophoresis buffer $(0.1 \mathrm{mM}$ Tris/HCI, $0.1 \mathrm{mM}$ boric acid, $0.002 \mathrm{mM}$ EDTA, pH 8.3) (Sambrook et al. 1989). The gel was stained with GelRed Nucleic Acid Gel Stain (Biotium, USA).

\section{Histopathology}

Fish were sacrificed with pitting technique, where the gills, eye, brain, and kidney tissue samples were collected every 4 hours post challenge (hpc), then fixed in $10 \%$ formaldehyde, and processed using a standard histological technique. After $24 \mathrm{~h}$ fixation, the tissue was trimmed before dehydrated in an ethanol series, followed by embedding in paraffin, and finally serial sectioning at $4 \mu \mathrm{m}$. The sections were stained routinely with haematoxylin and eosin (HE). Histopathological changes in each organ were semi quantitatively scored as none (0), mild (1), moderate (2), or severe (3).

\section{IHC}

Serial $4 \mu \mathrm{m}$ thick sections were cut from the paraffinembedded tissue blocks onto silane-coated glass slides. The slides were dried for $15 \mathrm{~min}$ at $56-60^{\circ} \mathrm{C}$, dewaxed in xylene and rehydrated through a graded alcohol series. The slides were washed with PBST for $10 \mathrm{~min}$. Endogenous peroxidase activity was blocked with freshly prepared 3\% hydrogen peroxide for $5 \mathrm{~min}$ in room temperature and rinsed and washed with PBST for 2 min. In enhancing the tissue to be immunoreactive, heat-mediated antigen retrieval with citrate buffer solution in microwave oven was used. Sections were blocked with blocking buffer 1\% normal serum (Bovine serum albumin) and PBST, then sections were incubated with tilapia anti S. agalactiae with the dilution of 1:50 for at least $1 \mathrm{~h}$ at $37^{\circ} \mathrm{C}$ in an incubator. Then the procedure was followed by rinsing and washing with PBST for 5 min. Sections were incubated again at $37^{\circ} \mathrm{C}$ for $30 \mathrm{~min}$ with secondary antibody (goat anti-tilapia) with the dilution of 1:100. The slides were rinsed and washed with PBST for $5 \mathrm{~min}$ before DAB was applied $1 \mathrm{ml}$ diluents to a 1 drop $\mathrm{DAB}$ for colour change. Once the sections became brown, the slides were immediately rinsed with distilled water and the slides were stained using Mayer's haematoxylin solution for the background colour.

\section{Statistical analysis}

Statistical analyses were performed using MedCalc for Windows, version 12.2.1.0 (MedCalc Software, Mariakerke, Belgium) and tested at $5 \%$ level of significance. The differences in the data of lesion scoring were analyzed using
Kruskal-Wallis and post-hoc tests were performed using Conover pairwise comparison test.

\section{Results}

\section{Clinical and macroscopic findings}

The clinical signs observed during $24 \mathrm{hpc}$ with $S$. agalactiae demonstrated haemorrhage around the eyes, operculum, fin and/or body, erratic swimming, c-shaped body curvature, imbalance, some were dull and were isolated from the others. The clinical signs were most obvious in fish that were challenged IP followed by IC and lastly by IM bath of live $S$. agalactiae. The signs were first noticed as early as $2 \mathrm{hpc}$ in the IP group, $4 \mathrm{hpc}$ in IC followed by IM 8 hpc. At 4 hpc, the lesions observed include enlarged and congested spleen, pale and haemorrhagic liver, engorged gall bladder, congested kidney and softening of the brain (Table 1).

\section{Mortality}

There was no mortality due to the infection at the end of the experiment $(24 \mathrm{hpc})$.

\section{Bacteria isolation and identification}

The primary isolates from the sampled organs (eye, brain and kidney) revealed small pinpoint or minute transparent colonies on blood agar. The colonies were minute $(0.5-1.0 \mathrm{~mm})$, transparent, round and convex entirely. The colonies were characteristically presumptive of Streptococcal spp., Gram-positive cocci in chains, single

Table 1 Semi quantitative scoring of eye, brain, and kidney in red tilapia, 0 . niloticus hybrid, challenge experimentally to different routes of infection

\begin{tabular}{|c|c|c|c|}
\hline & Brain & Eye & Kidney \\
\hline Lesion & $\begin{array}{l}\text { Infiltration of } \\
\text { mononuclear } \\
\text { cells, congestion, } \\
\text { detachment of } \\
\text { blood vessel, } \\
\text { hydrophic } \\
\text { degeneration }\end{array}$ & $\begin{array}{l}\text { Haemorrhage, } \\
\text { congestion, } \\
\text { infiltration of } \\
\text { mononuclear } \\
\text { cells, widening } \\
\text { of retina layer }\end{array}$ & $\begin{array}{c}\text { Hydropic } \\
\text { degeneration, } \\
\text { congestion, } \\
\text { haemorrhage, }\end{array}$ \\
\hline
\end{tabular}

\begin{tabular}{ccccc}
\hline Hour & Group & & & \\
4 & 1 & 3 & 2 & 3 \\
& 2 & 1 & 2 & 2 \\
& 3 & 1 & 1 & 2 \\
8 & 1 & 3 & 2 & 3 \\
& 2 & 1 & 3 & 2 \\
& 3 & 1 & 2 & 3 \\
16 & 1 & 3 & 2 & 3 \\
& 2 & 2 & 3 & 3 \\
& 3 & 2 & 3 & 3 \\
24 & 1 & 3 & 3 & 3 \\
& 2 & 3 & 3 & 3 \\
& 3 & 3 & &
\end{tabular}


Table 2 Results of microbiological examination of different groups and organs of red tilapia for S. agalactiae

\begin{tabular}{|c|c|c|c|c|c|c|c|c|c|}
\hline \multirow[b]{2}{*}{ Hour } & \multicolumn{3}{|c|}{ IP Group } & \multicolumn{3}{|c|}{ IM group } & \multicolumn{3}{|c|}{ IC group } \\
\hline & Brain & Eye & Kidney & Brain & Eye & Kidney & Brain & Eye & Kidney \\
\hline C & - & - & - & - & - & - & - & - & - \\
\hline 4 & + & + & + & - & + & - & - & + & - \\
\hline 8 & + & + & + & - & + & - & + & + & - \\
\hline 12 & + & + & + & - & + & + & - & + & + \\
\hline 16 & + & + & + & - & + & - & - & + & - \\
\hline 20 & + & + & + & - & - & - & - & - & - \\
\hline 24 & + & + & + & - & + & - & - & + & - \\
\hline
\end{tabular}

Note: (-) negative isolation; (+) positive isolation; (C) control.

or pairs and catalase negative. The biochemical profile of the isolates was confirmed by API rapid ID 32 Strep $^{\circ}$ (bioMerieux SA, Marcy I'Etoile, France) with 99.9\% sensitivity to $S$. agalactiae.

Table 2 shows the bacterial isolation from tilapia samples for every $4 \mathrm{~h}$ sampling. S. agalactiae was isolated from twelve tilapia from IP group, ten fish from IC group and seven fish from IM group.

\section{PCR}

Based on Figure $1 \mathrm{~A}$ and $1 \mathrm{~B}$, all the colonies that were subcultured were positive for S. agalactiae at 1457-bp. S. agalactiae were isolated in the target organs from the different routes of infection at every 4 till $24 \mathrm{hpc}$.

\section{Histopathology and lesion scoring}

$S$. agalactiae induced acute inflammation in the brain, eye and kidney. Histological lesions were more severe in IP followed by IC and lastly IM throughout the $24 \mathrm{hpc}$. The meninges of telecephalon and cerebellum were infiltrated with inflammatory cells which in some cases were accompanied by haemorrhage and mild infiltration of eosinophilic granular cells which were located dorsal to the fourth ventricle. The lesions were more severe in IP12 (intraperitoneal $12 \mathrm{hpc}$ ) compared to IM12 (immersion $12 \mathrm{hpc}$ ) and IC12 (immersion cut $12 \mathrm{hpc}$ ). Kidney tissue showed various degrees of degeneration, tubular necrosis, haemorrhage and infiltration of the inflammatory cells especially lymphocytes. The lesions were more severe in IP12 than IM12 and IC12. The eye lesions were characterized by a mild cellular infiltrate, comprising macrophages and eosinophils which were observed in the choroid and periorbital tissues $12 \mathrm{hpc}$. The meninges were congested and thickened with the presence of eosinophilic granular cells in the brain. Based on the lesion score, there was no significant difference $(P>0.05)$ between the lesion induced by the routes of infection in most of the organs except the brain.

IHC

In IP and IC administration, the intense staining of $S$. agalactiae antigen was observed in the blood vessels lumen and walls. While in the kidney, it was observed in the interstitial capillaries, areas of haemorrhage and necrosis with cellular infiltration, some were observed in the macrophages. S. agalactiae antigens were detected most in the meninges, the meningeal blood vessel lumen and wall. In the eye, the choroid was more affected with the periorbital area containing macrophages with $S$. agalactiae antigens. The pattern of immunostaining of the tissues with $S$. agalactiae followed similar pattern in the IM group with less intensity. The antigens were observed in the tissues (brain, eye and kidney) harvested at $24 \mathrm{hpc}$ in all the infected groups (Table 3; Figure 2).

\section{Discussion}

This investigation describes the clinicopathological changes and the immunohistochemical detection of antigens in acute experimental S. agalactiae infection in red tilapia. The red tilapia challenged with $S$. agalactiae

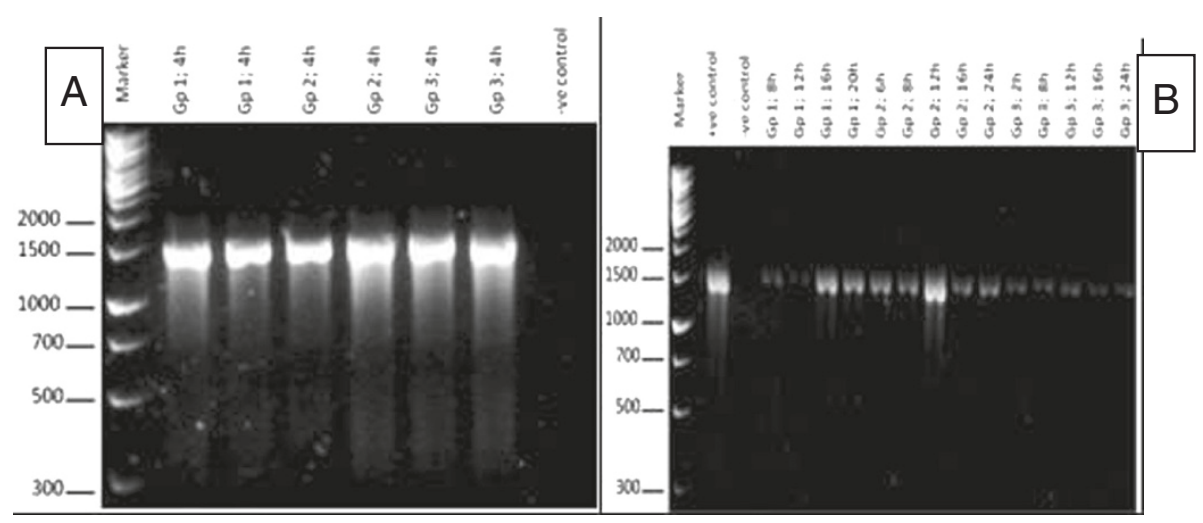

Figure $1 \mathrm{~A}$ and B: Ethidium bromide-stained 1.5\% agarose gel of multiplex PCR products. All the samples S. agalactiae substrains yielded a single 1457-bp product, indicating the presence of the $16 \mathrm{~s}$ ribosomal ARN gene sequence. Molecular size markers are shown on the left. (Gp, group; h, hour). 
Table 3 Results of IHC examination of different groups and organs of red tilapia for S. agalactiae

\begin{tabular}{cccc}
\hline Group & Brain & Eye & Kidney \\
\hline C & - & - & - \\
IM4 & - & - & - \\
IM12 & - & - & - \\
IM16 & + & + & + \\
IC8 & - & - & + \\
IP4 & + & - & + \\
IP8 & + & + & + \\
IP12 & + & + & + \\
IP16 & + & + & + \\
IP20 & + & + & + \\
IP 24 & + & + & + \\
\hline
\end{tabular}

showed various clinical signs and lesions that are consistent with the disease such as skin, fin and visceral organ haemorrhage/congestion while histopathological changes observed in the brain, kidney and eye are highly suggestive of septicaemia as observed in natural and experimental Streptococcal infection (Evans et al. 2002; Salvador et al. 2005; Suanyuk et al. 2005; Austin and Austin, 2007; Musa et al. 2009) with detection of bacterial in the tissues after $8 \mathrm{hpc}$.

The detection of $S$. agalactiae in tissues soon after infection further suggested the three organs as the target organ of the organism in the order of the brain, eye and kidney (Abuseliana et al. 2011). This observation was also reported for warm water streptococcosis associated with S. iniae in rainbow trout (Lahav et al. 2004). The gross pathological changes seen in this study were typical of

Note: (-) negative brown staining; (+) positive brown staining; (C) control.

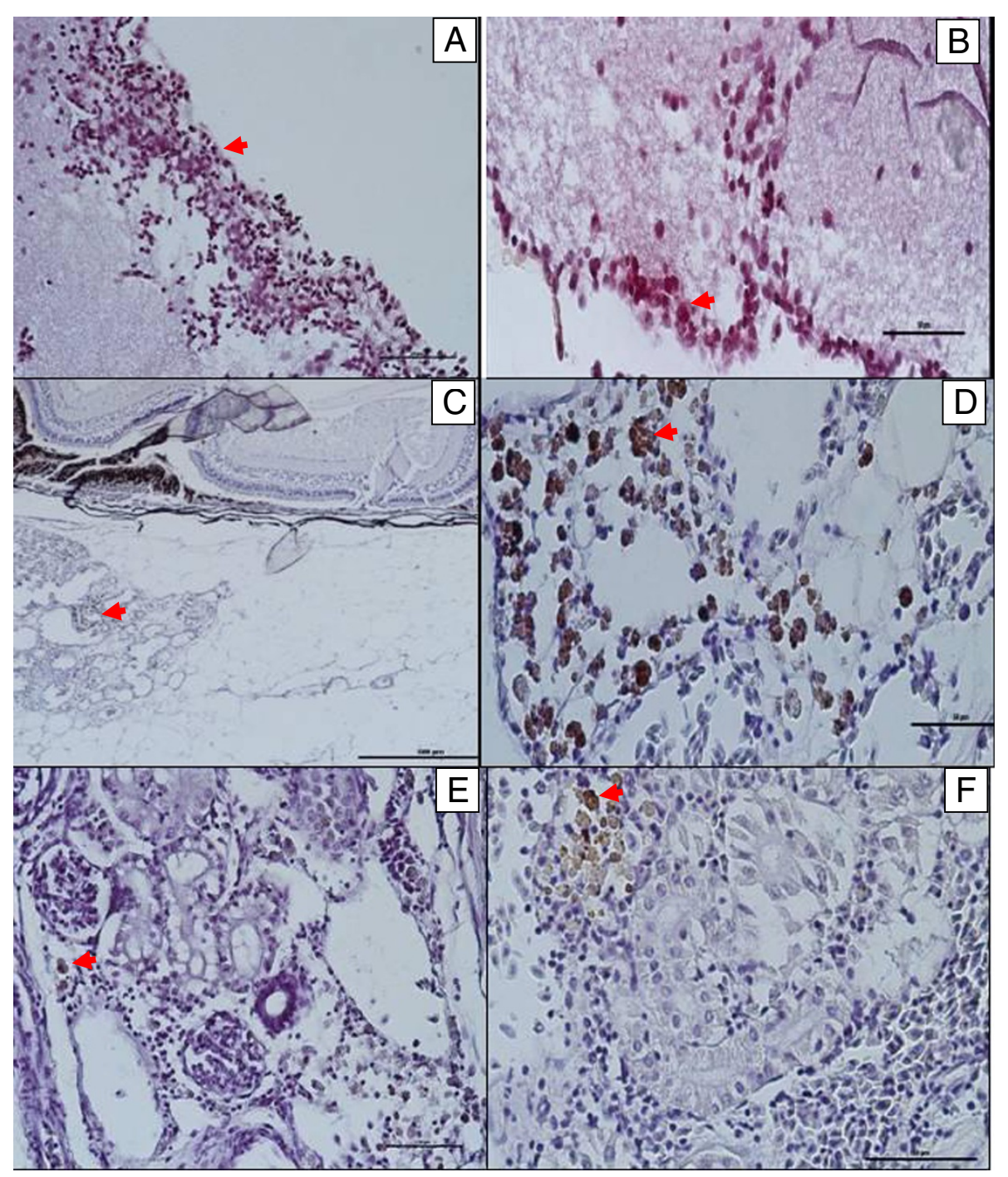

Figure 2 Streptococcus agalactiae antigens were found in A, B: the meninges and the meningeal blood vessel lumen and wall. C and D: blood vessels and capillaries in the periorbital area containing macrophages. $\mathbf{E}$ and $\mathbf{F}$ : in the kidney; in the blood vessels lumens, walls and interstitial capillaries. 
septicaemia associated with $S$. agalactiae infection. The meningitis and blood vessels congestion were associated with loss of orientation and abnormalities often associated with $S$. agalactiae neurotropism (Eldar et al. 1995; Abuseliana et al. 2011).

Although most experiments showed that tilapia are more susceptible to $S$. agalactiae by IP route than IM, this study showed that IC which mimic the situation on field is not totally different from the IP group which further showed that minor cut of the skin possibly due to cannibalism or aggression or mild injury due to netting could lead to increased susceptibility to S. agalactiae infection in tilapia.

The bacteria were isolated at $4 \mathrm{hpc}$ mostly from IP route in the brain, eye and kidney, followed by IC in the brain and eye lastly by IM in the brain only. This showed that brain is the primary target organ. The severity and wider distribution observed with IP route may be due to IP being a direct route of infection into the body when compared to the IC which had a means of entry into the body while IM has the natural skin defensive mechanisms to contend with. The effect on the blood vessel and subsequent detection of antigens in blood vessels, capillaries in the kidney and meningeal capillaries by IHC further lend credence to the report of Zamri-Saad et al. (2010) that vasculitis and thrombosis are some of the features of streptococcosis in tilapia.

There was no mortality within $24 \mathrm{~h}$ despite severe pathological changes observed within this period and this agreed with the report of Abuseliana et al. (2011) who reported mortality $48 \mathrm{hpc}$, while $50 \%$ of the challenge fish died on day 5 postchallenge. The fact that IP route had more lesion than IC and IM showed that the pathogenicity of the bacteria depends on level of septicaemia, with the brain being the primary target organ for $S$. agalactiae irrespective of the routes employed (Paperna 1996).

\section{Conclusions}

S. agalactiae has been recognized as pathogenic to fish especially tilapia causing septicaemia and severe pathological changes in all different routes of infection (24 hpc) used in this study. The lesions are observed in the brain, eye and kidney and are more severe in the IP route, followed by IC and lastly IM. The detection of the antigen by IHC in the blood vessel lumen and on the wall which is described for the first time proves vasculitis and septicaemia as the major pathogenesis and it also explain the role of IC route in streptococcosis in red tilapia.

\section{Competing interests}

All authors have contributed equally in this study. The authors declare that they have no competing interests.

\section{Authors' contributions}

SA carried out the experiment and collecting samples. NO carried out the experiment and collecting samples. SMY is a project leader and supervised the project. EBO carried out the immunoperoxidase and analyses. TPN carried out the immunoperoxidase and analyses. LH cut, trimmed and staining. JS cut, trimmed and staining. All authors are contributed equally in this study. All authors read and approved the final manuscript.

\section{Acknowledgements}

This project was funded by the Ministry of Higher Education, Malaysia (MOHE) under the FRGS5524030. We thank all the staff of AEC, Department of Fisheries Malaysia, Bukit Tinggi, Pahang and Histopathology Laboratory, Department of Veterinary Pathology \& Microbiology, Faculty of Veterinary Medicine, UPM for their excellent assistance.

Received: 8 February 2013 Accepted: 16 April 2013

Published: 28 June 2013

\section{References}

Abuseliana AF, Daud HHM, Abdul Aziz S, Khairani Bejo S, AlSaid M (2011) Pathogenicity of Streptococcus agalactiae isolated from a fish in Selangor to Juvenile Red tilapia (Oreochromis sp.). JAVA 10(7):914-919

Agnew W, Barnes AC (2007) Streptococcus iniae an aquatic pathogen of global veterinary significance and a challenging candidate for reliable vaccination. Vet Microbiol 122(1-2):1-15

Alcamo IE (1997) Fundamentals of Microbiology, 5th edn. Addison Wesley Longman, Inc, California, p 766

Amal AMN, Siti-Zahrah A, Zulkafli R, Misri S, Ramley A, Zamri-Saad M (2008) The effect of water temperature on the incidence of Streptococcus agalactiae infection in cage-cultured Red Tilapia. International Seminar on Management Strategies on Animal Health and Production Control in Anticipation of Global Warming, Surabaya, Indonesia, pp 48-51

Austin B, Austin DA (2007) Bacterial Fish Pathogens: Diseases of Farmed and Wild Fish. Praxis Publishing Ltd, Chichester

Chang PH, Plumb JA (2006) Histopathology of experimental Streptococcus sp. infection in tilapia, O. niloticus and channel catfish, Ictalarus punctatus. J Fish Dis 19:235-241

Eldar A, Bejerano Y, Livoff A, Horovitcz A, Bercovier H (1995) Experimental streptococcal meningo-encephalitis in cultured fish. Vet Microbiol 43:33-40

El-Sayed A-FATTAH (2006) Tilapia culture. CABI Publishing, UK

Evans JJ, Klesius PH, Gilbert PM, Shoemaker CA, Al Sarawi MA, Landsberg J, Duremdez R, Al Markouk A, Al Kenzi S (2002) Characterization of b-haemolytic group B Streptococcus agalactiae in cultured sea bream, Sparus auratus L., and wild mullet, Liza klunzingeri (Day), in Kuwait. J Fish Dis 25:505-513

Evans JJ, Klesius PH, Shoemaker CA (2004) Efficacy of Streptococcus agalactiae (group B) vaccine in tilapia (Oreochromis niloticus) by intraperitoneal and bath immersion administration. Vaccine 22:3769-3773

Ferguson HW, Morales JA (1994) Ostland. Streptococcosis in aquarium fish. Dis Aquatic Organism 19:1-6

Garcia JC, Klesius PH, Evans JJ, Shoemarker CA (2008) Non-infectivity of cattle Streptococcus agalactiae in Nile tilapia, Oreochromis niloticus and channel catfish, Ictalurus punctatus. Aquaculture 281:151-154

Klesius PH, Shoemaker CA, Evans JJ (2008) Streptococcus: A worldwide fish health problem. 8th International Symposium on Tilapia in Aquaculture, Cairo, Egypt, pp 83-107

Lahav D, Eyngor M, Hurvitz A, Ghittino C, Lublin A, Eldar A (2004) Streptococcus iniae type 11 infections in rainbow trout Oncorhynchus mykiss. Dis Aquatic Organism 62(1-2):177-180

Musa N, Wei LS, Hamdan RH, Leong LK (2009) Short communication: Streptococcosis in red tilapia (Oreochromis niloticus) commercial farm in Malaysia. Aqua Res 40:630-632

Nandlal S, Pickering T (2004) Tilapia fish farming in Pacific Island countries. Volume 1. Tilapia Hatchery Operation. Secretariat of the Pacific Community, Noumea, New Caledonia

Olivares-Fuster O, Klesius PH, Evans JJ, Airas CR (2008) Molecular typing of Streptococcus agalactiae isolates from fish. Fish Diseases 31:277-283

Paperna I (1996) Parasites, infections and diseases of fishes in Africa: An update. FAO/CIFA Technical Paper No. 31, p 220

Pasnik DJ, Evans JJ, Klesius PH (2006) Passive immunization of Nile tilapia Oreochromis niloticus provides significant protection against Streptococcus agalactiae. Fish Shellfish Immunol 21:365-371

Salvador R, Muller EE, Freitas JC, Leonhadt JH, Pretto-Giordano LG, Dias JA (2005) Isolation and characterization of Streptoccocus spp. group B in Nile tilapias 
(Oreochromis niloticus) reared in hapas nets and earth nurseries in the northern region of Parana State, Brazil. Ciencia Rural 35(6):1374-1378

Sambrook J, Fritsch EF, Maniatis T (1989) Molecular cloning: a laboratory manual, 2nd edn. Cold Spring Laboratory Press, N.Y. Cold Spring Harbour Laboratory, p 1656. ISBN 0-87969-309-6

Shoemaker CA, Evan JJ, Klesius PH (2000) Density and dose: factors affecting mortality of Streptococcus iniae infected tilapia Oreochromis niloticus. Aquaculture 188:229-235

Siti-Zahrah A, Misri S, Padilah B, Zulkafli R, Kua BC, Azila A, Rimatulhana R (2004) Pre-disposing factors associated with outbreak of Streptococcal infection in floating cage-cultured red tilapia in reservoirs. Abstracts of the 7th Asian Fisheries Forum 04. The Triennial Meeting of The Asian Fisheries Society, Penang, Malaysia, p 129

Siti-Zahrah A, Padilah B, Azila A, Rimatulhana R, Shahidan R (2005) In: Bondad-Reantaso MG, Mohan CV, Crumlish M, Subasinghe RP (eds) Proceedings of the sixth symposium on Diseases in Asian Aquaculture. , Colombo, Sri Lanka, pp 332-339

Suanyuk N, Kanghear H, Khongpradit R, Suparnattaya K (2005) Streptoccocus agalactiae infection in tilapia Oreochromis niloticus). Songklanakarin J Sci Technol 27:307-319

Zamri-Saad M, Amal MNA, Siti Zahrah A (2010) Pathological changes in red tilapia Oreochromis spp. naturally infected by Streptococcus agalactiae. J Comp Pathol 143:227-229

doi:10.1186/2193-1801-2-286

Cite this article as: Abdullah et al:: Clinicopathological features and immunohistochemical detection of antigens in acute experimental Streptococcus agalactiae infection in red tilapia (Oreochromis spp.). SpringerPlus 2013 2:286.

\section{Submit your manuscript to a SpringerOpen ${ }^{\circ}$ journal and benefit from:}

- Convenient online submission

- Rigorous peer review

- Immediate publication on acceptance

- Open access: articles freely available online

- High visibility within the field

- Retaining the copyright to your article 